\title{
A new species of the myrmecomorphic planthopper genus Formiscurra (Fulgoroidea: Caliscelidae) from Ethiopia
}

\author{
Vladimir M. GNEZDILOV \\ Zoological Institute of the Russian Academy of Sciences, Universitetskaya nab. 1, 199034, Saint Petersburg, Russia; e-mail: vmgnezdilov@mail.ru, \\ vgnezdilov@zin.ru
}

\author{
Accepted: \\ $15^{\text {th }}$ December 2018 \\ Published online: \\ $25^{\text {th }}$ January 2019
}

\begin{abstract}
Formiscurra atlas sp. nov. is described from southwestern Ethiopia. It represents the first record of the genus Formiscurra Gnezdilov \& Viraktamath, 2011 (Hemiptera: Fulgoroidea: Caliscelidae) from Africa. The relationships of Formiscurra to other African taxa of Caliscelidae as well as myrmecomorphy in Auchenorrhyncha are discussed. A photograph of a live specimen of Formiscurra indicus Gnezdilov \& Viraktamath, 2011 and an identification key to both species are given.
\end{abstract}

Key words. Hemiptera, Fulgoromorpha, Caliscelini, planthoppers, morphology, taxonomy, myrmecomorphy, Ethiopia, Afrotropical Region

Zoobank: http://zoobank.org/urn:1sid:zoobank.org:pub:2E227F82-F966-4820-9843-E6B0A1A1A15B

(C) 2018 The Authors. This work is licensed under the Creative Commons Attribution-NonCommercial-NoDerivs 3.0 Licence.

\section{Introduction}

Seven years ago a unique species representing a monotypic genus of the planthopper family Caliscelidae (Hemiptera: Fulgoroidea), Formiscurra indicus Gnezdilov \& Viraktamath, 2011, was described from Bangalore in southern India (GNEZDILOV \& VIRAKTAMATH 2011). The genus Formiscurra Gnezdilov \& Viraktamath, 2011 belongs to the tribe Caliscelini Amyot \& Serville, 1839 known only from the Old World (GNezDilov 2013). It is easily distinguished from other caliscelid genera by a peculiar ball-shaped process on the metope of the male and a long cylindrical process on the metope of the female. The genus was initially thought to be endemic to the Indian subcontinent. However, a second representative of Formiscurra was recently recognized in the Museo di Zoologia, Università degli Studi di Roma by Jérôme Constant (Brussels, Belgium) from specimens collected in southwestern Ethiopia, Omo National Park, nearly 70 years ago. Thanks to the information on this species kindly provided by J. Constant and efforts by Emanuele Piattella (Rome, Italy) to send the specimens for my study, it is described below.

\section{Material and methods}

The morphological terminology follows GnezDiLov (2003) and GNEZDiLov et al. (2014). Male genital segments were macerated for $1 \mathrm{~min}$ in boiling $10 \% \mathrm{KOH}$ solution. The drawings were made using a Leica MZ95 stereomicroscope with a camera lucida attachment. The photographs were taken using a Leica DFC 290 camera mounted on the same stereomicroscope. Images were produced using Helicon Focus 5.3 image stacking software and composed into plates using Adobe Photoshop CS6 software.

The type series of the new species described below was divided between the Museo di Zoologia, Università degli Studi di Roma "Sapienza", Rome, Italy (MZUR) and the Zoological Institute of the Russian Academy of Sciences, Saint Petersburg, Russia (ZIN).

\section{Taxonomy}

Formiscurra Gnezdilov \& Viraktamath, 2011

Formiscurra Gnezdilov \& Viraktamath, 2011: 235.

Type species. Formiscurra indicus Gnezdilov \& Viraktamath, 2011, by original designation.

\section{Formiscurra atlas sp. nov. (Figs 1-19)}

Type locality. Southwestern Ethiopia, Bench Maji Zone, Omo National Park, Uesca Ueca, ca. $5^{\circ} 49^{\prime} \mathrm{N}, 35^{\circ} 36^{\prime} \mathrm{E}$.

Type material. Holotype: ^ै, 'Uesca Ueca / Basso OMO / III - 40 Patrizi' (MZUR; dry-mounted, glued on a card label). PARATYPES: $2 \delta$ (missing some parts of the body and legs) $3+{ }_{+}$, same locality label as holotype (MZUR - 12 2 $+9, \mathrm{ZIN}-1 \lesssim 1 \%$ ). 
Description. Body length. Male - $5.3 \mathrm{~mm}$; females $5.6-5.7 \mathrm{~mm}$.

Male (Figs 1, 2, 8). Coloration. General coloration dark brown. Lateral margins of metope above eye level, median carina and margins of coryphe light yellow. Postclypeus medially and anteclypeus yellowish light brown. Rostrum light brown, with apex nearly black. Pedicel light yellow on the inner side. Pronotum with light yellow median carina and light yellow spots. Paranotal lobes with light yellow lower margins. Fore wings with wide ivory band medially (Figs 1, 2). Apices of leg spines black. Abdominal tergite III whitish light yellow except for dark brown lateral margins. Abdominal tergites IV-V yellowish light brown except for dark brown lateral margins. Abdominal tergites VI-VII brownish light yellow medially, except for dark brown median line, with lateral parts dark brown to black. Abdominal sternite III straw yellow with basal part dark brown (Fig. 8). Abdominal sternites VI-VII dark brown to black with yellowish margins. Fore and middle legs brown to dark brown. Hind femora with light yellow areas in upper third on inner edge. Pygofer and styles dark brown to black. Anal tube dark brown, with lateral margins yellowish brown.

Structure. Head and body with fore wings covered by sparse long setae (Fig. 1). Coryphe transverse, three times as wide as long at midline, without carinae; anterior margin four-angled; posterior margin weakly concave (Fig. 2).
Lower part of metope and upper part of postclypeus forming ball-shaped projection which is smooth and covered by long setae (Figs 1, 2). Ball-shaped projection with narrow basal part, enlarged apically, slightly flattened laterally. Metope wide, with lateral margins convex, weak and short median carina and very weak sublateral carinae only visible in its upper angles. Metopoclypeal suture convex, resting against base of ball-shaped projection. Postclypeus large and swollen. Coryphe and metope, in lateral view, joining at an obtuse angle (Fig. 1). Scape cylindrical, with one-side edge above the other. Pedicel cylindrical, with sensory organs and very long knife-shaped projection, flattened and pointed apically (Fig. 2). Flagellum twice as long as the knife-shaped projection of pedicel. Rostrum reaching hind coxae; third segment short and cylindrical; second segment three times as long as third one. Pronotum slightly longer than coryphe at midline, with short median carina extending from its posterior margin, but not reaching anterior margin. Paradiscal fields of pronotum narrow behind eyes. Paranotal lobes of pronotum wide, nearly triangular. Posterior margin of pronotum concave. Mesonotum large, 1.5 times longer than pronotum, with peculiar lateral carinae joining on scutellum (Fig. 10). Fore wings saddle-shaped, not reaching posterior margin of abdominal tergite III, with only radial veins visible. Femora and tibiae very long combined length of femur + tibia is comparable to length of head + body. Fore and hind legs longer than middle ones.

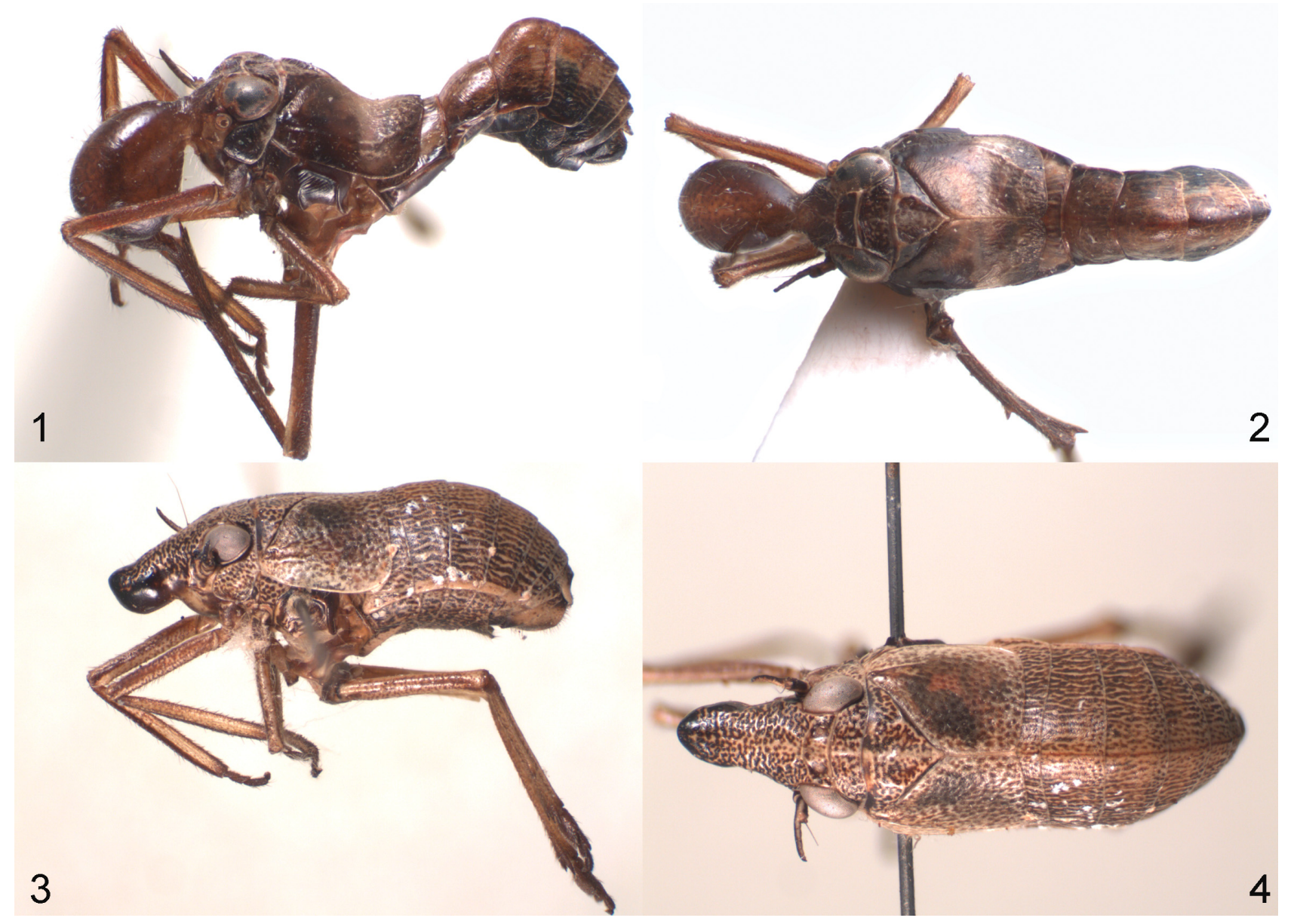

Figs 1-4. Formiscurra atlas sp. nov. 1 - male, holotype, lateral view; 2 - same, dorsal view; 3 - female, paratype, lateral view; 4 - same, dorsal view. Total length: male $-5.3 \mathrm{~mm}$, female $-5.7 \mathrm{~mm}$. 

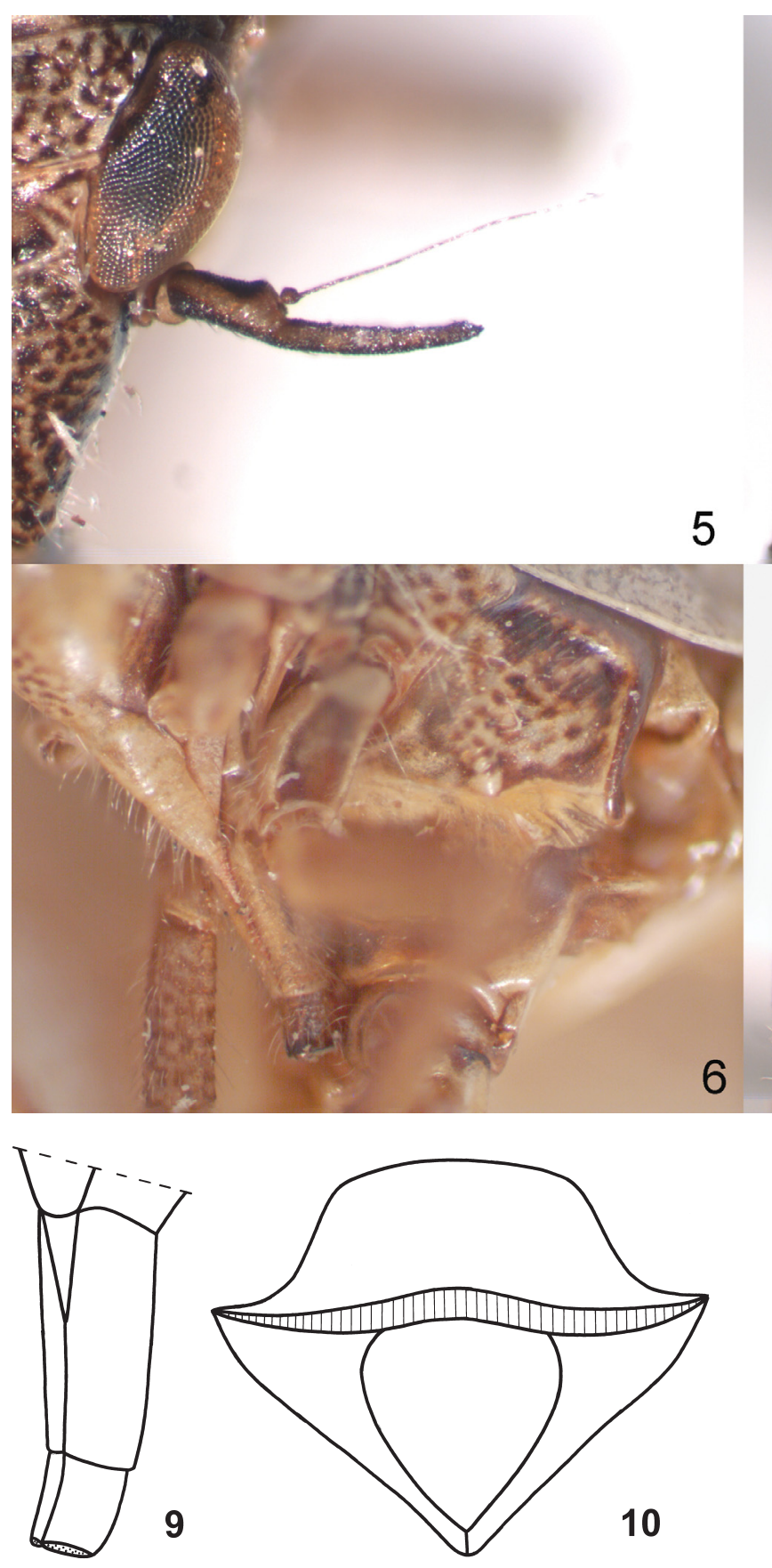

Figs 9-10. Formiscurra atlas sp. nov. 9 - female, paratype, rostrum, lateral view; 10 - male, holotype, pro- and mesonotum, dorsal view.

Fore tibiae slightly flattened laterally. Hind tibia with single lateral spine nearly at mid length and five apical spines. First metatarsomere as long as second and third ones combined, with two latero-apical spines and pad of hair-shaped setae. Abdomen, in lateral view, strongly curved posterior to tergite III; tergite V strongly convex; sternite III with concave trapezoidal posterior margin (Fig. 8); sternites IV-VI with wedge-shaped posterior margins.

Genitalia (Figs 11-19). Anal tube, in dorsal view, wide, clearly narrowing apically (Fig. 16); in lateral view, apex slightly turned down (Fig. 18). Pygofer with thick process on hind margins in its upper half(Figs 18, 19: pp). Penis wide, enlarged apically with drawn tip of apex, in lateral view, mushroom-shaped, and a pair of curved aedeagal hooks -

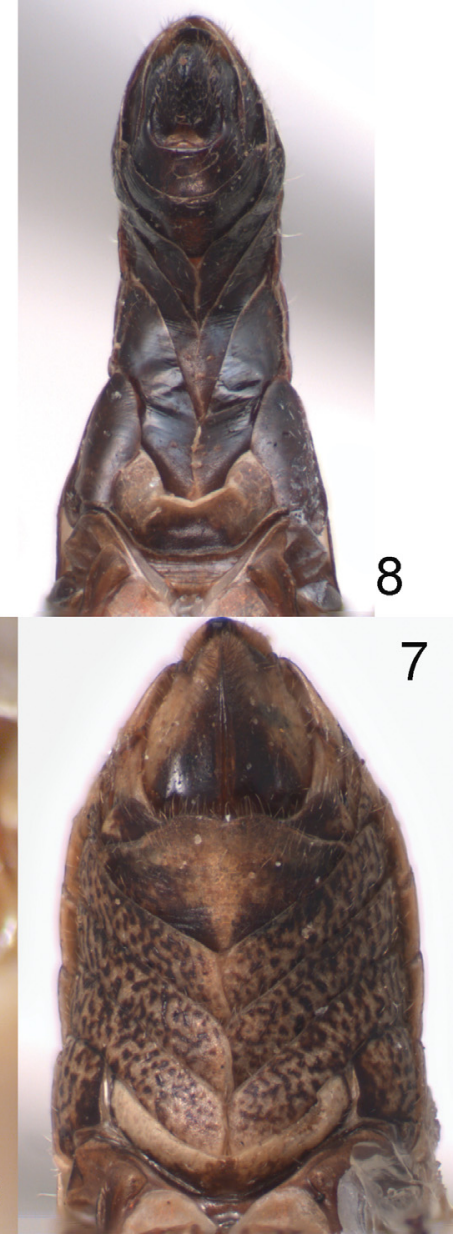

Figs 5-8. Formiscurra atlas sp. nov. 5 - female, paratype, antenna, dorsal view; 6 - female, paratype, rostrum, lateral view; 7 - female, paratype, abdomen, ventral view; 8 - male, holotype, abdomen, ventral view.

right one turned down and left one turned up (Figs 11-13). Connective with wide cup (Fig. 17). Style with narrow and long capitulum, without lateral tooth (Figs 14, 15).

Female. Coloration. General coloration of head and body including fore wings yellowish light brown with dense dark brown to black dots fused into tiny longitudinal stripes on abdominal tergites (Figs 3, 4). Metopial projection dark brown to shiny black apically and laterally (Fig. 3). Postclypeus yellowish light brown to black, with dark brown dots medially below metopial projection. Rostrum black apically. Scape dark brown. Pedicel dark brown to black outside and light yellow inside. Fore wings with whitish yellow costal margins. Legs with dark brown dots fused into marginal longitudinal stripes clearly visible on flattened fore tibiae. Tarsi dark brown to black. Abdominal tergites IV-VII with light yellow lateral margins. Abdominal sternite VII with dense dark brown dots fused into wide dark brown areas (Fig. 7). Anal tube light yellow, with wide dark brown median longitudinal stripe dorsally and ventrally. Gonoplacs dark brown from base to middle. Gonocoxae VIII dark brown except for light yellow proximal parts.

Structure. Head and body including fore wings covered by sparse long setae. Metope and metopial projection dorsally with dotted grooves. Metope with weak sublateral carinae. Metopial projection wide and thick, in dorsal view, with weak constriction, slightly flattened laterally from the base towards its apex, smooth ventrally and laterally (Figs $3,4)$. Pedicel cylindrical, with very long knife-shaped projection, flattened and pointed apically, and sensory organs 


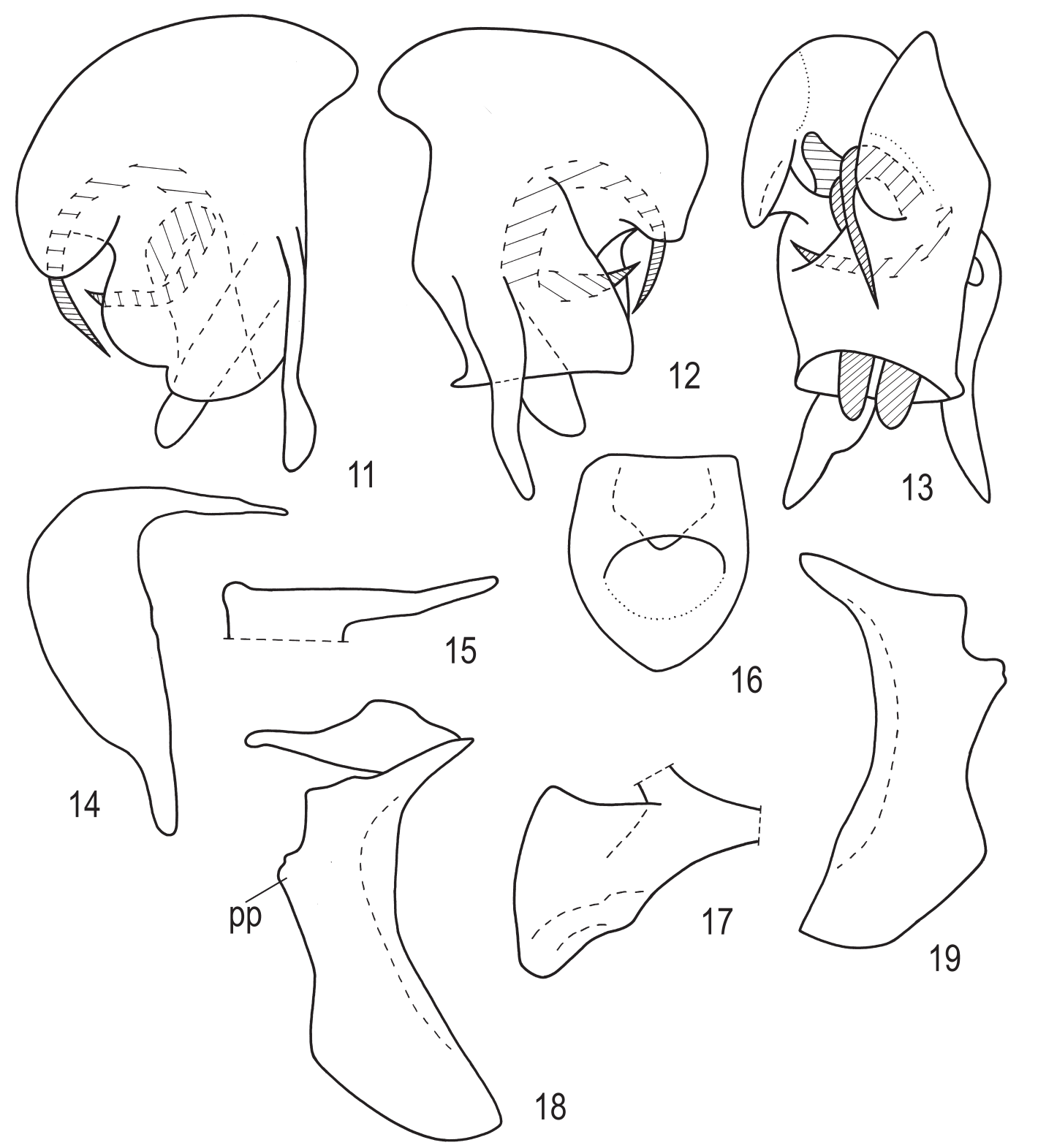

Figs 11-19. Formiscurra atlas sp. nov., paratype, male genitalia. 11 - penis, left lateral view; 12 - penis, right lateral view; 13 - penis, ventral view; 14 - style, lateral view; 15 - capitulum of style, dorsal view; 16 - anal tube, dorsal view; 17 - connective, lateral view; 18 - pygofer, left lateral view; 19 - pygofer, right lateral view. Abbreviation: pp - process of hind margins of pygofer.

covering also inner side of projection (Fig. 5). Rostrum reaching hind coxae; third segment short and cylindrical; second segment three times as long as third one (Figs 6, 9). Pronotum with smooth median carina. Mesonotum without carinae. Fore wings straight, not saddle-shaped, venation obscure (Figs 3, 4). Abdomen not curved in lateral view. Fore wings not reaching hind margin of abdominal tergite III. Fore tibiae slightly flattened. Hind tibiae with single lateral spine above their mid-length and five apical spines. First and second metatarsomeres as in males. Arolium, in dorsal view, not surpassing apices of claws. Abdominal sternite III massive, convex vertically (Fig. 7); sternites IV-VI deeply concave; sternite VII wide, with hind margin convex bearing median concavity (Fig. 7).

Diagnosis. See the key below.

Etymology. The species name is derived from the name of the Greek mythological character "A $\mathrm{\tau} \lambda \alpha \varsigma$ " - Titan support- ing the pillars that separate the Earth from the Sky - and should be treated as a noun in apposition.

\section{Key to species of Formiscurra}

\section{Males:}

1 Fore wings brown to dark brown or black, each with an opalescent green (in live specimens, Fig. 20) or whitish (in dry specimens) large spot (GNEZDILOv \& VIRAKTAMATH 2011: Figs 3, 5). Apices of both aedeagal ventral hooks directed downwards (GNEZDILOV \& ViRAKTAMATH 2011: Fig. 10). Total body length 4.6-5.1 mm. ...... F. indicus Gnezdilov \& Viraktamath, 2011

- Fore wings dark brown to black, with a wide ivory band (Figs 1, 2). Right aedeagal hook directed upwards, left one turned downwards (Figs 11-13). Total body length $5.3 \mathrm{~mm}$. F. atlas sp. nov. 


\section{Females:}

1 Metopial projection, in dorsal view, smoothly narrowing apically; in lateral view, 1.5 times as long as wide (GNEZDilov \& ViRAKTAMATH 2011: Figs 6, 7). Generally darker, head and body with a broad longitudinal pale stripe along midline dorsally (Gnezdilov \& Viraktamath 2011: Figs 6, 7). Total body length $5 \mathrm{~mm}$.

F. indicus Gnezdilov \& Viraktamath, 2011

- Metopial projection, in dorsal view, with weak constriction (Fig. 4); in lateral view, 1.15-1.25 times as long as wide (Fig. 3). Generally lighter, head and body without longitudinal pale stripe dorsally (Fig. 4). Total body length $5.6-5.7 \mathrm{~mm}$.

F. atlas sp. nov.

\section{Discussion}

Formiscurra atlas sp. nov. was collected in the Omo National Park which is situated in southwestern Ethiopia near the border with Kenya. With their curved body, saddle-shaped fore wings, and long, not flattened legs, both currently known Formiscurra species are close to Populonia curvata (Melichar, 1908) known from Tanzania and Kenya (GNezdilov \& Bourgoin 2009: Fig. 16). Both Formiscurra species and $P$. curvata are characterized also by robust females differing externally from the males (GNEzDiLov \& Bourgoln 2009: Fig. 18). However, P. curvata does not display any ball-shaped metopial projection in the male and possesses only a very short and rounded projection of the pedicel in both sexes. In the structure of male genitalia, P. curvata differs from both Formiscurra species in the phallobase which is widely rounded apically, with one of the phallobase lateral lobes possessing a large hook-shaped projection and the other lobe with a row of small teeth, and the pygofer lacking a process on its hind margins.

Live males of $F$. indicus display a large opalescent green spot on each fore wing (Fig. 20) which turns whitish in dry specimens. Similar opalescent green spots are found in live males of Caliscelis (Cerepa) carnavalis Emeljanov, 2015 and C. (C.) gnezdilovi Emeljanov, 2015 from Vietnam (EMELJANov 2015: Figs 7-10). The ivory-coloured band on the fore wings of $F$. atlas sp. nov. is similar to that of Caliscelis (Bambula) swazi Gnezdilov \& Bourgoin, 2009 from southern Africa (GNEzDILov \& BourgoIN 2009: Figs 7, 8). The male of $C$. swazi is similar to F. atlas sp. nov. also in the saddle-shaped fore wings. Formiscurra species and C. (B.) swazi are close in the structure of the asymmetrical, mushroom-shaped phallobase, with drawn tip of phallobase apex and two lateral folds of dorso-lateral lobes covering the aedegal hooks (Figs 11, 12) (GNEZDILOV $\&$ Bourgoin 2009: Figs 63, 65). However, Formiscurra species have aedeagal hooks directed both upwards and downwards, while in C. (B.) swazi both hooks are directed downwards.

So far, only two genera of Caliscelidae are known to be distributed from India to tropical Africa - Rhinogaster Fennah, 1949 and Chirodisca Emeljanov, 1996. Rhinogaster comprises two Indian and one South African species. Chirodisca includes two species of which C. eximia (Stål, 1859 ) is widely distributed in India, Sri Lanka, Pakistan, Nepal, Sudan, Erithrea, and Tanzania (GnezDiLov \& BourGOIN 2009, GNEZDILOv 2011). I hypothesized (GNEZDILOv 2011) that these genera originated in Eurasia and spread to Africa between Miocene and Pliocene (5-7 million years ago) after the Tethys sea closed and would thus represent remnants of the Hipparion fauna which was

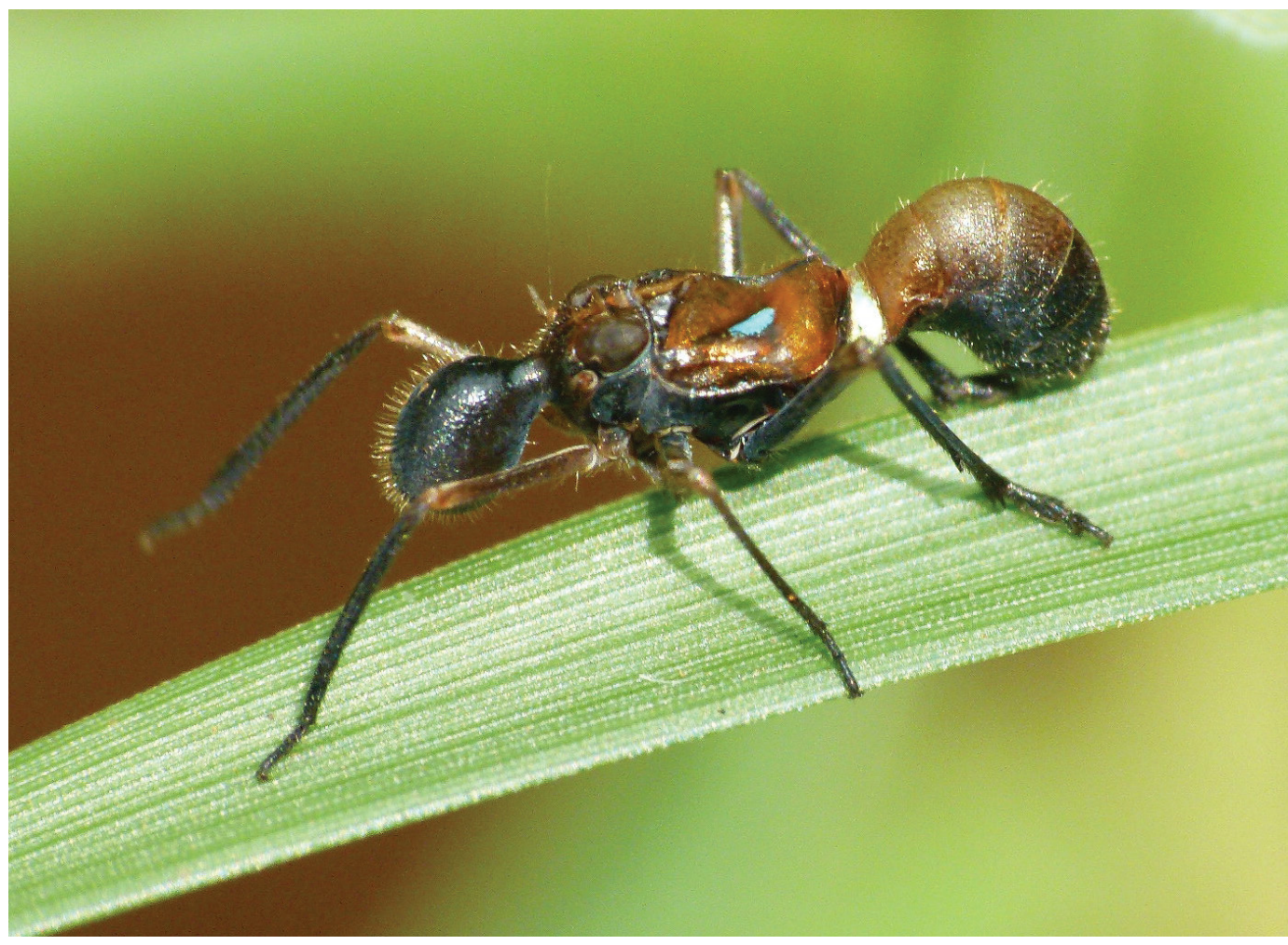

Fig. 20. Formiscurra indicus Gnezdilov \& Viraktamath, 2011. Photograph by Shyamal Lakshminarayanan, 23th June 2013 south Bangalore, India, 12.8093026 N $77.4796312 \mathrm{E}$. 
widely distributed in Eurasia in Miocene (MeKaEv 1987). Formiscurra may be also added to this group of taxa.

More than 2000 species of myrmecomorphic arthropods are known (McIver \& StONEDAHL 1993). According to McIver \& STONEDAHL (1993: 351) myrmecomorphy “... forms a subset of ant mimicry, which includes all species that resemble ants through behavioral, chemical, or textural characters." Within Auchenorrhyncha, bright examples of taxa mimicking bees and wasps were described among sharpshooters (Cicadomorpha: Cicadellidae: Cicadellinae; MeJDALANI et al. 2002) but myrmecomorphy seems to be rare. McIver \& Stonedahl (1993) listed just the treehopper genus Heteronotus Laporte, 1832 (Cicadomorpha: Membracidae) referring to Poulton (1898: fig. 6) who described the resemblance of a large process on pronotum of $H$. trinodosus Butler, 1878 to the body of an ant. Other myrmecomorphic taxa of Membracidae include $H$. flavolineatus Laporte, 1832 (reported by BOUlard 1999), Cyphonia clavata (Fabricius, 1787 ) with a process of pronotum imitating an ant of the subfamily Myrmicinae "... facing towards the back of the treehopper" (MADERSPACHER \& STENSMYr 2011) and the genus Stegaspis Germar, 1833 the larva of which imitates a leaf-cutting ant (according to PoulTON 1898: fig. 7). The case described by Poulton (1898) for H. trinodosus is a "concealment of the body behind a mask" according to CотT (1957: 409): “ ... the pronotum is immensely enlarged, being similar in form to the body of the ant, and extending backwards so as completely to cover, like a shield, the otherwise unaltered body". By analogy I assume that the ball-shaped process on the head of Formiscurra species conceals the head of the planthopper behind a mask of an ant abdomen. The similarity of the metopial bulb in males of Formiscurra indicus to an ant abdomen was already mentioned as a case of morphological convergence by GNEZDILOV \& VIRAKTAMATH (2011: 239). Apparently, only males of Formiscurra mimic ants. Why females do not? This question remains open and cannot be answered without observations in nature. Similar sexual dimorphism, with one of the sexes mimetic and the other one non-mimetic, was reported in Heteroptera (Miridae) and spiders (Araneidae) (MCIver \& STONEDAHL 1993). Another potentially myrmecomorphic African species of Caliscelidae, Myrmissus bellicosus Linnavuori, 1973, was described only from males, while females are still unknown (Linnavuori 1973, Gnezdilov \& Bourgoin 2009). The behaviour of Caliscelidae and their potential predators is almost unknown. O'Brien (1988: 867) mentioned that specimens of Asarcopus palmarum Horváth, 1921 “... were found in the axils of the leaf fronds [of the palm Caryota urens L.], as many as three in a group, being guarded by ants Camponotus sp." in India. However, this is rather an indication of myrmecophily than myrmecomorphy.

\section{Acknowledgements}

I thank Dr. Emanuele Piattella (Rome, Italy) for sending the specimens for my study, Mr. Jérôme Constant (Brussels, Belgium) who drew my attention to this material and reviewed the manuscript, Mr. Shyamal Lakshminarayanan (Bangalore, India) for the picture of live F. indicus, Prof. Dr. Hannelore Hoch (Berlin, Germany) for her useful com- ments on the manuscript, and Dr. Fedor V. Konstantinov (Saint Petersburg, Russia), Dr. Adéline Soulier-Perkins (Paris, France), Dr. Charles R. Bartlett (Newark, Delaware, USA), and Dr. Daniela Maeda Takiya (Rio de Janeiro, Brazil) for valuable literature references. My study was supported by the Alexander von Humboldt Stiftung (Bonn, Germany) and performed in the framework of the Russian state research project no. AAAA-A17-117030310210-3.

\section{References}

BOULARD M. 1999: Contributions à l'Entomologie générale et appliquée. 2. Cicadaires (Rhynchota Auchenorrhyncha). 2me partie: Membracoidea. 1. Notes et documents. Ecole Pratique des Hautes Etudes, Biologie et Evolution des Insectes (principalement Hemipteroidea ou Rhynchota) 11/12: 141-182.

COTT H. B. 1957: Adaptive coloration in animals. Methuen \& Co, London, 508 pp. +48 pl.

EMELJANOV A. F. 2015: A subgeneric subdivision of the genus Caliscelis Lap. with description of new species (Homoptera, Caliscelidae). Entomologicheskoe Obozrenie 94: 684-697 [in Russian, English translation published in Entomological Review (2015) 95: 918-930].

GNEZDILOV V. M. 2003: Review of the family Issidae (Homoptera, Cicadina) of the European fauna, with notes on the structure of ovipositor in planthoppers. Chteniya Pamyati N. A. Kholodkovskogo [Meetings in Memory of N. A. Cholodkovsky] (St. Petersburg) 56(1): 1-145 (in Russian, English summary).

GNEZDILOV V. M. 2011: A new species of the genus Rhinogaster Fennah (Homoptera, Fulgoroidea, Caliscelidae) from southern Africa. Entomologicheskoe Obozrenie 90: 881-884 + 1 pl. [in Russian, English translation published in Entomological Review (2012) 92: 93-96].

GNEZDILOV V. M. 2013: Modern system of the family Caliscelidae Amyot et Serville (Homoptera, Fulgoroidea). Zoologicheskii Zhurnal 92: 1309-1311 [in Russian, English translation published in Entomological Review (2014) 94: 211-214].

GNEZDILOV V. M. \& BOURGOIN T. 2009: First record of the family Caliscelidae (Hemiptera: Fulgoroidea) from Madagascar, with description of new taxa from the Afrotropical Region and biogeographical notes. Zootaxa 2020: 1-36.

GNEZDILOV V. M. \& VIRAKTAMATH C. A. 2011: A new genus and new species of the tribe Caliscelini Amyot \& Serville (Hemiptera: Fulgoroidea: Caliscelidae: Caliscelinae) from southern India. Deutsche Entomologische Zeitschrift 58: 235-240.

GNEZDILOV V. M., HOLZINGER W. E. \& WILSON M. R. 2014: The Western Palaearctic Issidae (Hemiptera, Fulgoroidea): an illustrated checklist and key to genera and subgenera. Proceedings of the Zoological Institute of the Russian Academy of Sciences 318(Supplement 1): $1-124$.

LINNAVUORI R. 1973: Hemiptera of the Sudan, with remarks on some species of the adjacent countries. 2. Homoptera Auchenorrhyncha: Cicadidae, Cercopidae, Machaerotidae, Membracidae and Fulgoroidea. Notulae Entomologicae 53: 65-137.

MADERSPACHER F. \& STENSMYR M. 2011: Myrmecomorphomania. Current Biology 21(9): R291-R293.

McIVER J. D. \& STONEDAHL G. 1993: Myrmecomorphy: morphological and behavioral mimicry of ants. Annual Review of Entomology 38: 351-379.

MEJDALANI G., TAKIYA D. M., FELIX M., CEOTTO P. \& YANEGA D. 2002: Teletusa limpida (Signoret): a Neotropical proconiine leafhopper that mimics megachilid bees (Hymenoptera: Apoidea), with notes on Batesian mimicry in the subfamily Cicadellinae (Hemiptera: Cicadellidae). Denisia 4 (zugleich Kataloge des Oberösterreichischen Landesmuseums), N.F. 176: 215-224.

MEKAEV Yu. A. 1987: Zoogeographicheskie kompleksy Evrazii. [Zoogeographical complexes of Eurasia.] Nauka, Leningrad, 125 pp. (in Russian).

O'BRIEN L. B. 1988: Taxonomic changes in North American Issidae (Homoptera: Fulgoroidea). Annals of the Entomological Society of America 81: 865-869.

POULTON E. B. 1898: Natural selection the case of mimetic resemblance and common warning colours. Journal of the Linnean Society, Zoology 26: $558-612+$ pls $40-44$. 